\title{
Correspondence
}

To the Editor:

Permit me to comment on Aviva Halamish's review of my book, Palestine: A Twice-Promised Land? vol. 1 (Bulletin, vol. 36, no. 1, pp. 33-34).

I am pleased that she subscribes to my thesis that Palestine was excluded from McMahon's promise to the Sharif Hussein. However, with regard to the Weizmann-Feisal Agreement, she totally misread the text. She writes that "the blame for the failure of the [Weizmann-Feisal Agreement of 1919] rests mainly on the Jews who 'failed to make their promised financial and territorial assistance good'." This statement, as noted in my book - and which is attested to there by very careful documentation - was made by Feisal, by then King of Iraq, in 1922, when angling for financial largesse from the Rothschild family. The sum that he expected was so fantastic that even a well-to-do banker like Rothschild could not pay it. Feisal used the charge, perhaps humourously, as a bargaining ploy, but Dr. Halamish apparently took it seriously.

It was Feisal who reneged on his agreement with Weizmann. The Foreign Office arrived at the conclusion that he was a "political opportunist" (p. 28), whereas Weizmann referred to him as a "broken reed." I regret that Dr. Halamish overlooked that section of my book.

Isaiah Friedman

Ben-Gurion University of the Negev

Aviva Halamish responds:

I thank Professor Friedman for his clarification regarding the source of the statement that the blame for the failure of the Weizmann-Feisal agreement of 1919 rests mainly on the Jews who "failed to make their promised financial and territorial assistance good." Mea Culpa! And I apologize for what may be conceived as a distorted representation of his meticulous survey of the episode entitled "The Weizmann-Feisal Agreement and After."

However, I would like to somewhat refute his allegation that I "totally misread the text," and suggest that probably it is more a matter of misinterpretation. Friedman's elaborate description of the agreement, the correspondence following it and some retrospective evaluations of it, still left my curiosity not fully satisfied as to why, as Prof. Friedman put it, "the 
agreement proved to be abortive" (p. 238). As to Faisal's motivations for signing the agreement in the first place, what seems to be closest to an answer in the book is: "He believed that, in the long run, the Palestinian Arabs would benefit from Jewish colonization" (p. 238). The failure of the Jews to deliver any sign that this belief will ever come true is not totally irrelevant in trying to understand the agreement's failure. Moreover, the quoted statement caught my attention (and of course one must be selective in reviewing a 300 page book in 500 words) because it is in line with an established claim, that the Zionist movement missed the window of opportunities in the early years of British rule in Palestine because it failed to raise the necessary funds to economically materialize the political chances. This feeling was both expressed and partially produced by Weizmann's repeated outcry (in the Zionist Conference of 1920 and other occasions): "That is what we have done. Jewish people, what have you done?" aiming at the Jewish well-to-do who did not meet his expectations regarding the financing of the Zionist enterprise in Palestine.

Aviva Halamish

The Open University of Israel

\section{A Correction}

The author of the review of Stephen Heydemann, War, Institutions and Social Change in the Middle East (volume 36, no. 2, pp. 248-49), was wrongly listed as F. Gregory Gause,III. The author of the review was Ellen Lust-Okar, of Yale University. Please note the change in your own copy of the Bulletin. 